\title{
Update on the Epidemiology and Treatment of Giant Cell Arteritis
}

\author{
Matthew J. Koster, $M D^{1}$ \\ Kenneth J. Warrington, $M D^{1}$ \\ Tanaz A. Kermani, MD, $M S^{2, *}$
}

\author{
Address \\ ${ }^{1}$ Department of Internal Medicine, Division of Rheumatology, Mayo Clinic College \\ of Medicine, 200 First Street SW, Rochester, MN, 55905, USA \\ ${ }^{*}, 2$ Department of Medicine, Division of Rheumatology, David Geffen School of \\ Medicine, University of California Los Angeles, 2020 Santa Monica Boulevard, \\ Suite 540, Los Angeles, CA, 90404, USA \\ Email:TKermani@mednet.ucla.edu
}

Published online: 11 April 2016

C) Springer International Publishing AG 2016

This article is part of the Topical Collection on Vasculitis

Keywords Giant cell arteritis · Epidemiology · Treatment · Immunosuppression • Glucocorticoids • Biologic agents

\section{Opinion statement}

Giant cell arteritis is the most common form of primary systemic vasculitis in people over the age of 50 years. This disease affects the aorta and its branches, and complications may include vision loss, arterial stenosis, and aortic aneurysm. Early recognition and treatment of giant cell arteritis is important to mitigate long-term damage. While glucocorticoids remain the mainstay of treatment, relapses are common and morbidity related to treatment frequently occurs. There is an unmet need for immunosuppressive therapies that are able to induce long-term remission while avoiding the adverse effects of glucocorticoids. of available conventional immunosuppressive treatments, methotrexate is generally considered a first-line steroid-sparing agent for patients with disease refractory to glucocorticoids and in those at high risk for glucocorticoid-associated toxicity. Advances in understanding of disease pathogenesis continue to identify potential therapeutic targets, and several biologic agents are currently under investigation. Preliminary reports from controlled studies demonstrate potential efficacy of tocilizumab and abatacept in both newly diagnosed and relapsing patients; however, use of these agents should not yet be considered standard therapy. The role of anti-platelet therapy in prevention of ischemic complications is controversial, but low-dose aspirin is considered reasonable in this population. Statin medications have little role in the management of giant cell arteritis (GCA) and should be reserved for those with clinical indications for lipid reduction. Correction of arterial stenosis with surgical revascularization is uncommonly required for patients with refractory ischemic symptoms. Intervention should be performed in patients 
with quiescent disease. Monitoring for late-onset complications, particularly thoracic aortic aneurysm, should take place though the frequency of screening and the optimal timing of intervention is not established.

\section{Introduction}

Giant cell arteritis (GCA) is a chronic, granulomatous, large-vessel vasculitis that selectively affects the aorta and its primary and secondary branches $[1 \bullet]$. The most common presenting symptom of GCA is headache,

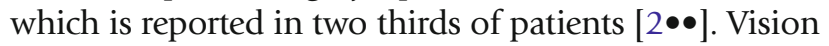
loss from ischemia of the optic nerve may occur in $20 \%$ patients and is considered an ophthalmologic emergency $[2 \bullet \bullet, 3]$. While GCA was previously known as "temporal arteritis," it is a systemic vasculitis whose clinical manifestations include ischemia from largeartery stenosis/occlusion and aortic manifestations including aneurysm formation and dissection [4•]. Timely diagnosis and initiation of therapy is therefore essential to mitigate the morbidity and mortality associated with both the acute presentation and long-term complications of this disease.
Glucocorticoids (GCs) have remained the mainstay of treatment induction and maintenance of remission for the past 50 years, and attempts at identifying beneficial steroid-sparing agents have been disappointing. Nevertheless, there continues to be an unmet need as treatment-associated morbidity from GC is observed in 73-100 \% of patients $[5 \bullet 6]$.

Recent advances in genetic analyses have provided a greater understanding of the epidemiology and pathogenesis of this disease, resulting in potential targets for therapeutic intervention. This review will focus on these epidemiologic updates as well as the advances in both conventional and targeted therapeutics in the management of GCA (Fig. 1).

\section{Epidemiology}

Nearly all of the studies evaluating the incidence of GCA are from Europe and USA which may reflect the demographic that is most frequently affected by GCA. Majority of the available studies evaluating the epidemiology of GCA in the literature are over two decades old. Caution must be used in interpreting the results since in these studies, the GCA diagnosis is often based on cranial manifestations of GCA or 1990 American College of Rheumatology (ACR) classification criteria. Therefore, these studies do not capture the subset of patients who present with large-artery manifestation who often do not meet ACR classification criteria [ $7 \bullet \bullet$ ]. In one study from Olmsted County, Minnesota which did include patients with large-vessel confirmation, no change was noted in the overall incidence of GCA even after inclusion of these patients [9].

Age, ethnicity, and sex are consistent risk factors for GCA based on currently available epidemiology studies [10]. In nearly all published studies of patients with GCA, women are affected two to four times more often than men.

\section{Age}

GCA almost never occurs in individuals below the age of 50 years [11]. In a systematic literature review, only 2 out of 1435 subjects $(0.1 \%)$ from 26 studies were younger than 50 years of age [11]. In most studies, the mean age at diagnosis of GCA is in the eighth decade of life [10]. Further strengthening the association between age and risk of GCA are several studies where the incidence of GCA 


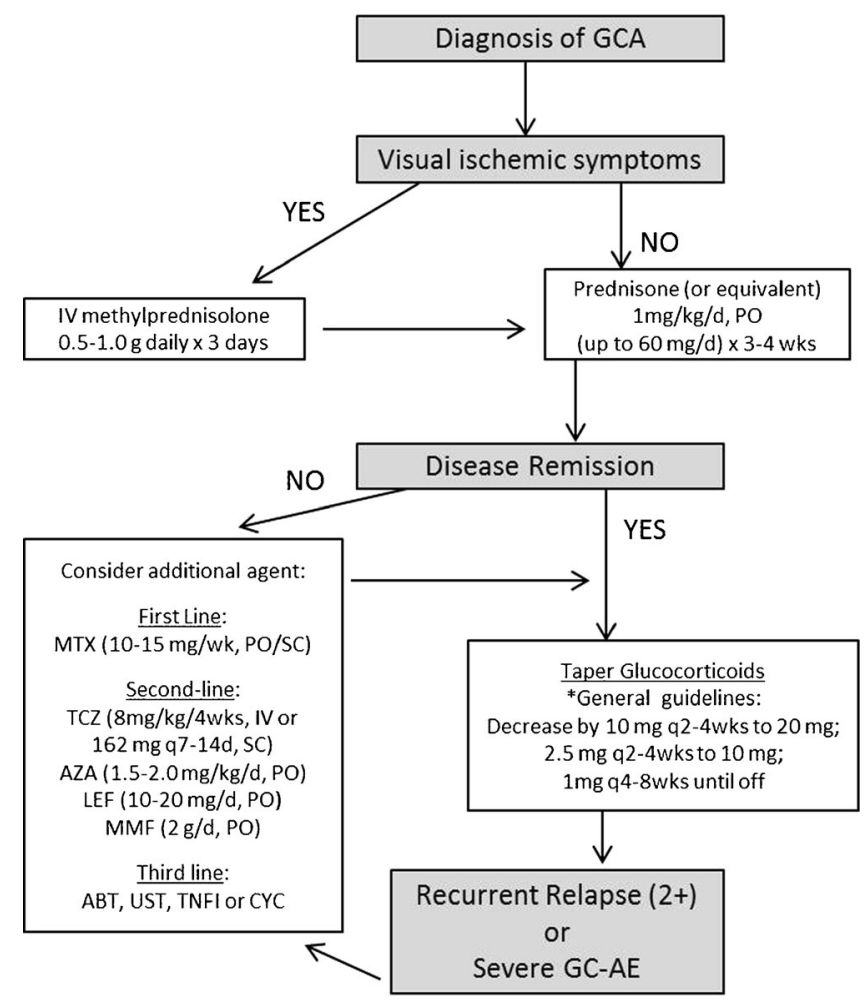

Fig. 1. Treatment recommendations for giant cell arteritis.

increases with each increase in decade of age $[9,12,13,14 \bullet, 15]$. Three studies have found that the mean age at diagnosis of GCA has increased in recent years, and this is not explained by demographic changes in the populations [16-18].

\section{Europe}

The highest incidence rates for GCA are from the Scandinavian countries. The highest estimated incidence reported is from Ribe County, Denmark with an annual incidence of 76.6 per 100,000 people $\geq 50$ years [19]. Rates of between 14 and 32.8 per 100,000 people $\geq 50$ years have been reported from other Scandinavian countries [13, 20-25]. Much lower incidence rates of between 2.2 to 10 per 100,000 people $\geq 50$ years have been reported from other European countries [15, 26-30]. The higher incidence of GCA in countries in Northern Europe suggests that latitude may affect risk. However, a study evaluating geographic variation in incidence of GCA within the UK showed higher incidence for areas in the south of the UK compared to the north [30].

\section{The Americas}

The estimated incidence of GCA in population-based studies from Olmsted County, Minnesota is similar to that observed in Scandinavian countries (18.9 per 100,000 people $\geq 50$ years) perhaps reflecting the Scandinavian background 
of the population in this region [9]. Few other studies have evaluated the epidemiology of GCA in North America. In a study from Shelby County, Tennessee, the estimated annual incidence of GCA was 2.4 per 100,000 people $\geq 50$ years in Whites [31]. A study from Saskatoon, Canada estimated the incidence of GCA at 9.4 per 100,000 people $>50$ years [32]. GCA appears to be rare among non-Caucasian populations in North America. The estimated annual incidence in African Americans was 0.36 per people $\geq 50$ years [31] and 1 per 100,000 people $\geq 50$ years in Alaska Natives [33].

The incidence of GCA in other ethnic groups in the Americas is not well studied. In the study from Saskatoon, only 2 of the 35 patients (5.7 \%) with GCA were of Aboriginal descent [32]. In a study, from University of California San Francisco, only 1 of 38 patients (2.6\%) with positive temporal artery biopsy was Asian [34].

Likewise, the incidence of GCA for the Hispanic population is not well known. Most of this data is based on small series reported from different centers. This includes a small case series of 11 patients from Puerto Rico [35]. In another series, 257 patients who had undergone temporal artery biopsy at a tertiary care center were contacted for information on their race [36]. No differences were observed between the rates of temporal artery biopsy positivity among those who identified themselves as Hispanic (20\%) compared to nonHispanic patients (28\%) [36]. Majority of the Hispanic population from this study was Cuban-American [36]. Likewise, estimates of the incidence of GCA in South America are also not available with only one published case series of 22 patients from a center in Mexico (Mestizo population) [37].

\section{Australia and New Zealand}

Two studies are available evaluating the epidemiology of GCA in this region. Both studies evaluated only subjects who underwent temporal artery biopsies,

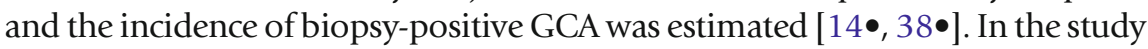
from Otago, New Zealand, the estimated annual incidence of GCA as 12.7 per 100,000 patients $\geq 50$ years of age [ $38 \bullet$, while the study from South Australia reported a lower incidence rate of 3.2 per 100,000 people $>50$ years [14 $\bullet$.

\section{Other reports}

The estimated incidence of GCA in Israel is 11.3 per 100,000 people $\geq 50$ years [39]. Significantly lower incidences have been reported from Turkey (1.13 per 100,000 people $\geq 50$ years) [40] and Japan ( 1.47 per $100,000 \geq 50$ years) [41]. Case reports have been published from Mumbai, India [42] and Riyadh, Saudi Arabia [43], Tunisia [44].

Given the demographic of patients who are most commonly affected by GCA, genetic factors likely play an important role in susceptibility. Not unexpectedly, the strongest genetic association is with the major histocompatibility complex (MHC) genes and with genes involved in regulation of the immune system [45••]. The strongest and most consistent genetic association of GCA is with MHC class II alleles, especially HLA DRB ${ }^{*} 04$ allele [ $\left.7 \bullet \bullet, 45 \bullet \bullet\right]$. In a large-scale genetic analysis, which included patients with GCA from Europe and North America, non-MHC associations (not reaching genome-wide significance) were 
observed including PTPN22 (a central negative regulator of T and B cells which has also been associated with various autoimmune diseases [46•]), REL (encodes a member of the nuclear factor- $\kappa \mathrm{B}$ family of transcription factors), and LRRC32 (encodes a protein that is expressed in activated T regulatory cells)

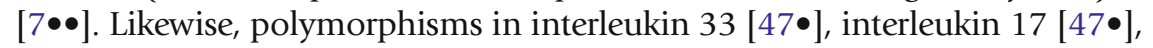
toll-like receptors, other cytokines, and molecules involved in endothelial function have been evaluated, but the sample sizes and lack of replication limit the ability to draw any conclusions at this time [45••].

\section{Environmental factors}

Few studies have found cyclic pattern or seasonal variations (increased incidence summer months in majority of studies) suggesting environmental triggers for GCA, but these remain poorly understood $[12,14 \bullet, 25,38 \bullet, 39,48,49]$. Recent studies from one group have reported the presence of varicella zoster virus in biopsies of patients with GCA, but these findings need to be replicated [50 $\bullet$. Socioeconomic status was associated with increased risk of ischemic events in one study from the UK [51] but not in another study from Sweden [52]. In one study, a higher prevalence of GCA was noted in urban populations [29].

\section{Treatment}

Prompt initiation of high-dose glucocorticoids (GCs) remains the cornerstone of remission induction treatment for GCA. The guidelines for use of GC are based on decades of clinical experience and expert consensus opinion. Initial dose and tapering regimens, however, have never been formally studied with prospective randomized trials. For patients with severe ischemic manifestations, particularly evolving visual loss, some experts recommend pulse-dose treatment with intravenous methylprednisolone (0.5-1.0 g, daily for three consecutive days) prior to high-dose oral GC in attempts to mitigate further visual compromise [53]. In the absence of acute visual ischemic complications, high-dose oral prednisone (or equivalent) is advocated by both the European League Against Rheumatism (EULAR) [1 mg/kg/day, up to maximum $60 \mathrm{mg} /$ day] [54] and the British Society for Rheumatology (BSR) [40-60 mg/day] [53]. Continuation of high-dose GC until symptoms and laboratory abnormalities resolve, usually 3-4 weeks, is suggested prior to initiating a gradual taper [53, 54]. The duration of GC treatment is highly variable and depends on the individual patient's disease course and propensity to relapse. Furthermore, the presence of extracranial large-vessel involvement (LV-GCA) portends the likelihood of a higher GC cumulative dose, longer GC treatment duration, and more frequent

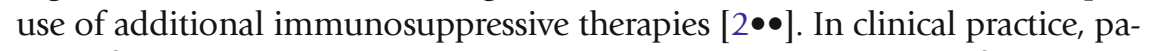
tients frequently require long-term GC therapy with up to $46 \%$ of patients remaining on GC at 5 years after initial diagnosis [ $5 \bullet$.

In an attempt to limit cumulative GC exposure and reduce the frequency of GC-associated adverse events (GC-AEs), various GC regimens have been investigated. While alternate-day dosing has proven less effective than daily dosing [55], the long-term GC-sparing effect of induction with pulse-dose steroids in non-complicated GCA has shown conflicting results $[56,57]$. Investigators have also proposed that lower initial GC doses may be as effective as high-dose 
regimens for GCA [58-60]. A retrospective study performed by Les et al. evaluated patients receiving initial daily treatment with medium-dose $(\leq 30 \mathrm{mg})$ or high-dose (>30 mg) prednisone [61]. The primary endpoint of clinical and biological remission (on a prednisone maintenance dose of $\leq 7.5 \mathrm{mg} /$ day) was reached in a shorter time among those started on a medium-dose compared to those on a high-dose regimen (median 186 vs. 236 days), without an increase in GCA complications. The mean cumulative prednisone dose at 6 months was $1.4 \mathrm{~g}$ greater in the high-dose cohort, and GC-AE were more frequent (medium dose $43 \%$, high dose $66 \%$ ). However, differences between the two groups, including a higher percentage of baseline ocular ischemic manifestations in the high-dose cohort as well as more frequent use of methotrexate and methylprednisolone pulses in the medium-dose group, limit interpretation of these results.

In contrast, the benefit of initial high-dose oral GC was observed by Labarca and Koster et al. in a large retrospective study evaluating prednisone use and associated outcomes [5•]. Among the 286 patients with biopsy-proven GCA followed for a median of 5 years, patients receiving an initial oral prednisone dose $>40 \mathrm{mg} /$ day (mean $60.2 \mathrm{mg} /$ day; $0.9 \pm 0.2 \mathrm{mg} / \mathrm{kg}$ ) were able to reach a dose of $<5 \mathrm{mg} /$ day [hazard ratio (HR) 1.46 (95\% CI 1.09, 1.96)] and discontinue prednisone [HR 1.56 (95\% CI 1.09, 2.23)] sooner than patients receiving $\leq 40 \mathrm{mg} /$ day (mean $36.3 \mathrm{mg} /$ day; $0.6 \pm 0.2 \mathrm{mg} / \mathrm{kg}$ ) without an increase in observed GC-AE.

Although GC use leads to rapid resolution of systemic inflammatory symptoms and reduction in the risk of vision loss, significant limitations of treatment remain. Indeed, chronic subclinical vascular inflammation often persists despite GC therapy. Lymphocytic infiltration in vascular lesions is largely driven by two $\mathrm{T}$ cell subsets: Thelper type 17 (Th17) and Thelper type 1 (Th1) cells [62••]. Acute inflammation, mediated by Th17 cells, is notably sensitive to GC suppression, whereas the Th1 response is refractory to GC and Th1 cells drive chronic vascular inflammation [63]. Indeed, in a unique GCA study in which repeat temporal artery biopsy was performed in patients on GC therapy, active vasculitis was found in the second biopsy in $75 \%$ of patients at 6 months and in $44 \%$ at 12 months [64]. The persistence of subclinical inflammation despite GC treatment and the high frequency of relapses during GC tapering underscores that GCA is a chronic immune-mediated condition requiring long-term treatment and that more effective immunosuppressive agents are needed.

Conventional immunosuppressive agents

In patients at high risk of GC-AE or in those requiring prolonged high-dose GC for disease control, steroid-sparing agents should be considered. Although both EULAR and BSR guidelines $[53,54]$ provide such recommendations, the optimal timing of initiation, choice of immunosuppressive agent, and preferred dosing remain unknown.

\section{Methotrexate}

Of the limited available evidence from clinical trials, methotrexate is the most studied conventional immunosuppressive agent. Nevertheless, three randomized controlled trials evaluating methotrexate (7.5-15 mg/week) in newly diagnosed patients with GCA have provided discordant results [65-67]. A metaanalysis of the combined 84 patients treated with methotrexate compared to the 77 patients receiving placebo found a modest response in reduction of 
cumulative GC dose and a higher probability of achieving sustained GC discontinuation. However, a reduction in GC-AE was not observed [68]. Overall, it was estimated that four patients with GCA would need to be treated with methotrexate for up to 48 weeks in order to prevent a first relapse and ten patients to prevent a first cranial relapse. Even though supportive data is sparse, methotrexate currently remains the most frequently considered adjuvant immunosuppressive agent for patients with relapsing GCA or GC-related toxicity.

\section{Cyclophosphamide}

Several retrospective studies have evaluated oral and intravenous cyclophosphamide in patients with refractory GCA [69-71, 72•]. De Boysson et al. reviewed 88 previously published cases and described an additional 15 patients with relapsing GCA treated with cyclophosphamide [72•]. Although overall $86 \%$ of patients experienced clinical and laboratory response, the utility of cyclophosphamide is limited by a significant rate of relapse after discontinuation (25\%) and a high frequency of treatment-limiting adverse events (40\% of patients) [72•]. Therefore, routine use of cyclophosphamide is not currently recommended.

\section{Leflunomide}

Two small uncontrolled studies have shown that leflunomide may be an effective steroid-sparing agent for patients with GCA that is refractory to GC or methotrexate $[73,74]$. Among leflunomide responders, the clinical improvement, laboratory marker reduction, and prednisone decrease were observed within 2-3 months after initiation. These preliminary results, however, are limited by short duration of follow-up among a small number of patients, and prospective trials are needed.

\section{Azathioprine}

One randomized, double-blind, placebo-controlled study has evaluated azathioprine in patients with GCA and/or polymyalgia rheumatica [75]. Among the 31 patients enrolled, 16 received $150 \mathrm{mg}$ daily azathioprine in addition to standard GC treatment. A statistically significant reduction in prednisolone dose was observed only after 52 weeks in the treatment group compared to those receiving placebo $(1.9 \pm 0.8 \mathrm{vs} .4 .2 \pm 0.6 \mathrm{mg})$. Data regarding the effect on $\mathrm{GC}-\mathrm{AE}$ and relapses is not provided. Given the low dose of prednisolone at study entry $(8.1 \pm 0.4 \mathrm{mg}$ azathioprine group vs. $7.4 \pm 0.4 \mathrm{mg}$ placebo group) and the lack of information on baseline disease characteristics, it is uncertain how to incorporate azathioprine in current clinical practice.

\section{Mycophenolate mofetil}

Data regarding the use of mycophenolate mofetil in GCA is limited to a single case series. Sciascia et al. [76] reported the use of adjunct mycophenolate (2 g/ day) in three patients with new onset GCA and high risk for GC-AE. Clinical response including symptom alleviation, inflammatory marker normalization, and rapid prednisone reduction was observed within 1 month. Additionally, despite the accelerated GC taper, no signs of clinical relapse were observed at a 
median follow-up of 22 months. Mycophenolate has also shown preliminary effectiveness in Takayasu arteritis, another major form of large-vessel vasculitis [77]. Therefore, further investigation into the use of this agent for treatment of GCA is warranted.

\section{Targeted biologic agents}

\section{Tumor necrosis factor alpha inhibitors}

The role of tumor necrosis factor alpha (TNF- $\alpha$ ) in the pathophysiology of GCA is uncertain. Prior reports noted increased expression of TNF- $\alpha$ in the temporal arteries of patients with active GCA [78], but more recent studies have not shown significant elevation of serum TNF- $\alpha$ levels in patients with GCA [79•]. Although TNF- $\alpha$ inhibitors have shown utility in Takayasu arteritis, none of the three randomized controlled trials evaluating TNF- $\alpha$ inhibitors in GCA have shown significant therapeutic efficacy [80-82]. However, the inclusion criteria for these studies focused primarily on patients with cranial symptoms. Therefore, whether patients with predominant LV-GCA features may benefit from these agents is unknown.

\section{Interleukin-6 inhibitors}

Because of the central role of interleukin-6 (IL-6) in GCA, biologic agents targeting this cytokine pathway are being actively investigated as therapeutic options. Tocilizumab, a humanized monoclonal IL-6 receptor blocker, has shown promise in several observational studies and is currently being evaluated in randomized controlled trials. The first trial evaluating the efficacy of this medication was reported in abstract form by Adler et al. [83]. Thirty patients with GCA (23 newly diagnosed, 7 relapsing) were randomized $2: 1$ to treatment or placebo. Among the 20 patients receiving intravenous tocilizumab $(8 \mathrm{mg} / \mathrm{kg} / 4$ weeks), complete remission at 12 weeks ( 85 vs. $40 \%$ ) and relapse-free survival at

52 weeks ( 85 vs. $20 \%$ ) were higher compared to the placebo group.

A multicenter, randomized, double-blind, placebo-controlled study evaluating subcutaneous tocilizumab (162 mg every 7 or 14 days) in patients with newly diagnosed and relapsing GCA is nearing completion (GiACTA-Clinicaltrials.gov identifier NCT01791153). A total of 241 patients with GCA have been enrolled, making this the largest controlled trial in GCA to date. A randomized controlled trial evaluating sirukumab, a fully human anti-interleukin-6 immunoglobulin G1-kappa with high affinity and specificity for binding the human IL-6 molecule, is also underway (ClinicalTrials.gov identifier NCT02531633).

\section{Abatacept}

Activated T cells are present in the vascular lesions of patients with GCA and are considered to play a pivotal role in disease pathogenesis [63]. Abatacept, a fusion protein composed of the Fc region of the immunoglobulin IgG1 fused to the extracellular domain of cytotoxic T-lymphocyte-associated protein 4 (CTLA4), blocks the co-stimulatory signal required for T cell activation. A multicenter, randomized, placebo-controlled trial evaluating the safety and efficacy of 
abatacept in GCA (Clincaltrials.gov identifier NCT00556439) has been completed, and preliminary results are available in abstract form [84]. Following a remission induction phase, 41 patients were randomized to abatacept or placebo. Relapse-free survival at 12 months ( 48 vs. $31 \%$ ) and duration of remission (median 9.9 vs. 3.9 months) were higher in the treatment group compared to placebo. While initial results are promising, complete trial data analysis and further study are needed before determining effectiveness.

\section{Future biologic options}

Increased understanding of the cellular mediators and cytokine profiles involved in the pathophysiology of GCA is providing additional molecular targets for possible intervention. Anakinra, an IL-1 type 1 receptor antagonist, has been used in three refractory GCA cases with encouraging results [85]. Further investigation of IL-1 inhibition is underway in a clinical trial evaluating the efficacy of gevokizumab, a monoclonal antibody against IL-1 $\beta$ (European Clinical Trials Database identifier 2013002778-38). Ustekinumab, a monoclonal antibody against IL-12/23p40, has shown initial promise in a small open-label study [86]. Although B cells are not considered the primary pathogenic cellular mediator in GCA, rituximab has been used in two patients with noted benefit [87, 88]. Further evaluation of these targeted therapeutics in larger cohorts and prospective trials are necessary prior to consideration for routine usage.

Adjunct medication

\section{Anti-platelet}

Preclinical studies using mice engrafted with inflamed human temporal arteries have shown that acetylsalicylic acid (ASA) is an effective inhibitor of cytokine transcription through suppression of interferon-gamma. In these murine studies, the combination of ASA and corticosteroids had synergistic effects on proinflammatory cytokine reduction in the vascular lesions of GCA [89]. Variable results, however, have been observed in retrospective clinical studies evaluating the efficacy of ASA in patients with GCA. While some studies conclude that use of anti-platelet/anti-coagulation therapy prior to GCA diagnosis reduces the risk of visual or cerebrovascular ischemic complications [90, 91], other studies have not replicated these findings [92, 93]. Indeed, in one cohort study, patients on anti-platelet or anti-coagulation therapy had a higher frequency of GCA-related severe cranial ischemic complications [94]. A recent meta-analysis concluded that treatment with anti-platelet/anti-coagulation therapy prior to GCA diagnosis does not protect against the development of severe ischemic complications. However, anti-thrombotic therapy may provide modest protection (odds ratio $0.32 ; 0.10-0.99$ ) from incident severe ischemic complications in patients with established GCA on GC therapy [95••]. The effect of ASA on disease activity and relapse is poorly understood, and retrospective reviews demonstrate discordant results $[5 \bullet, 96]$. While there is a need for prospective effectiveness trials, at current, both EULAR [54] and BSR [53] guidelines recommend treatment with ASA $75-150 \mathrm{mg} /$ day, unless contraindicated. 


\section{Statins}

Statin medications, which are inhibitors of 3-hydroxy-3methylglytaryl coenzyme A (HMG-CoA) reductase, possess pleotropic properties including reducing thrombogenicity, improving endothelial dysfunction, as well as providing immunomodulatory and anti-inflammatory effects [97]. Therefore, the potential benefit of these medications in patients with GCA is of clinical interest. Although one population-based study observed that patients treated with statins were less likely to develop GCA [98], these results have not been replicated by other investigators. In a French case-control study, Pugnet et al. observed a modest effect of baseline statin exposure on the likelihood of achieving remission maintenance with low-dose prednisone (HR 1.9), though no difference was seen in the overall cumulative prednisone dose [99•]. Nevertheless, the use of statin medications among patients with GCA in additional retrospective studies has not shown a significant clinical impact in decreasing ischemic events or preventing relapses [98, 100, 101]. Consequently, statin medications are not considered requisite adjuncts in the management of GCA and should be reserved for patients with approved clinical indications for lipid-lowering treatment.

Extracranial large-vessel involvement in GCA is frequently seen. Autopsy studies $[102,103]$ have shown that $90-100 \%$ of patients with GCA have arteritis in the aorta, subclavian, or axillary arteries, and recent studies using advanced imaging confirm that radiographic evidence of vascular inflammation can be seen in up to $83 \%$ at diagnosis [8]. Nevertheless, critical limb ischemia from stenotic lesions in GCA is uncommon due to frequent development of adequate collateral circulation. Surgical reconstructive procedures are rarely needed as $89-100 \%$ of patients presenting with upper extremity claudication remain stable or improve with medical management alone $[2 \bullet \bullet, 104]$. On the other hand, patients with lower extremity involvement are at a higher risk of progression necessitating revascularization, which may be required in $11-26 \%$ of cases $[105,106]$. If required, revascularization should take place when arterial inflammation is quiescent [54].

The risk of aortic aneurysm and dissection is also increased in patients with GCA [4•]. Although more frequently observed as a late complication, aneurysm/ dissection may also be present at diagnosis in a subset of patients. At current, there are no consensus guidelines regarding the method or frequency of aneurysm screening. In the absence of prospective studies in this population, treatment strategies and timing of intervention have been based on management of atherosclerotic aneurysms [107]. The comparative efficacy of endovascular repair to surgical resection has not been studied, but positive outcomes have been seen with both techniques.

\section{Conclusions}

Genetic analyses of patients with GCA are providing additional information regarding possible cellular and cytokine-mediated pathways that could be involved in the pathogenesis of this condition. However, due to the relative rarity of this disease, current investigations have been limited by cohort size, highlighting the need for further international collaborative efforts. 
Treatment with glucocorticoids remains essential in the management of GCA but is complicated by associated side effects. The benefit of conventional immunosuppression in this condition remains less well understood. Agents showing potential benefit need to be evaluated in well-designed prospective studies to identify efficacy.

Several targeted biologic therapies are currently under investigation. At this time, tocilizumab and abatacept currently show preliminary value in management of both newly diagnosed and refractory GCA. Further information regarding the efficacy of these and other agents is eagerly awaited.

\title{
Compliance with Ethical Standards
}

\author{
Conflict of Interest \\ MJK, KJW, and TAK declare that they have no conflicts of interest.
}

Human and Animal Rights and Informed Consent

This article does not contain any studies with human or animal subjects performed by any of the authors.

\section{References and Recommended Reading}

Papers of particular interest, published recently, have been highlighted as:

- Of importance,

• Of major Importance

1. Jennette JC, Falk RJ, Bacon PA, Basu N, Cid MC, Ferrario F, et al. 2 revised International Chapel Hill Consensus Conference Nomenclature of Vasculitides. Arthritis Rheum. 2013;65(1):1-11.

This publication includes an international consensus statement on the names and definitions of systemic vasculitis. In addition to updates on suggested classification of vasculitis (expands on the previous classification by vessel size), updated nomenclature is also addressed.

2.• Muratore F, Kermani TA, Crowson CS, Green AB, Salvarani C, Matteson EL, et al. Large-vessel giant cell arteritis: a cohort study. Rheumatology (Oxford). 2015;54(3):463-70.

Largest single-center study evaluating the treatment and outcomes of patients with giant cell arteritis and upper extremity arterial involvement. The study found differences in the baseline characteristics and prognosis of these patients.

3. Weyand CM, Goronzy JJ. Clinical practice. Giant-cell arteritis and polymyalgia rheumatica. N Engl J Med. 2014;371(1):50-7.

4. Kermani TA, Warrington KJ, Crowson CS, Ytterberg SR, Hunder GG, Gabriel SE, et al. Large-vessel involvement in giant cell arteritis: a population-based cohort study of the incidence-trends and prognosis. Ann Rheum Dis. 2013;72(12):1989-94.
Population-based study evaluating large-vessel complications in patients with giant cell arteritis and the long-term outcome including increased mortality in subjects with aortic manifestations.

5. $\quad$ Labarca C, Koster MJ, Crowson CS, Makol A, Ytterberg SR, Matteson EL, et al. Predictors of relapse and treatment outcomes in biopsy-proven giant cell arteritis: a retrospective cohort study. Rheumatology (Oxford). 2015 Sep 18 [E-pub].

Largest North American single center cohort evaluating glucocorticoid use and outcomes among biopsy-proven patients with giant cell arteritis. Patients with higher initial prednisone doses were able to taper and discontinue steroids sooner without increased risk of associated adverse events.

6. Alba MA, Garcia-Martinez A, Prieto-Gonzalez S, Tavera-Bahillo I, Corbera-Bellalta M, Planas-Rigol E, et al. Relapses in patients with giant cell arteritis: prevalence, characteristics, and associated clinical findings in a longitudinally followed cohort of 106 patients. Medicine (Baltimore). 2014;93(5):194-201.

7.• Carmona FD, Mackie SL, Martin JE, Taylor JC, Vaglio A, Eyre $S$, et al. A large-scale genetic analysis reveals a strong contribution of the HLA class II region to giant cell arteritis susceptibility. Am J Hum Genet. 2015;96(4):565-80. 
The findings of a large, multicenter study of the genetic susceptibility in patients with giant cell arteritis. The study confirms prior reports of the association of HLA class II alleles in addition to novel findings of other non-HLA alleles which may provide insight into the pathophysiology of giant cell arteritis.

8. Blockmans D, de Ceuninck L, Vanderschueren S, Knockaert D, Mortelmans L, Bobbaers H. Repetitive 18F-fluorodeoxyglucose positron emission tomography in giant cell arteritis: a prospective study of 35 patients. Arthritis Rheum. 2006;55(1):131-7.

9. Chandran AK, Udayakumar PD, Crowson CS, Warrington KJ, Matteson EL. The incidence of giant cell arteritis in Olmsted County, Minnesota, over a 60-year period 1950-2009. Scand J Rheumatol.

2015;44(3):215-8.

10. Gonzalez-Gay MA, Vazquez-Rodriguez TR, Lopez-Diaz MJ, Miranda-Filloy JA, Gonzalez-Juanatey C, Martin J, et al. Epidemiology of giant cell arteritis and polymyalgia rheumatica. Arthritis Rheum. 2009;61(10):1454-61.

11. Smetana GW, Shmerling RH. Does this patient have temporal arteritis? Jama. 2002;287(1):92-101.

12. Salvarani C, Crowson CS, O'Fallon WM, Hunder GG, Gabriel SE. Reappraisal of the epidemiology of giant cell arteritis in Olmsted County, Minnesota, over a fifty-year period. Arthritis Rheum. 2004;51(2):264-8.

13. Mohammad AJ, Nilsson JA, Jacobsson LT, Merkel PA, Turesson C. Incidence and mortality rates of biopsyproven giant cell arteritis in southern Sweden. Ann Rheum Dis. 2015;74(6):993-7.

14. Dunstan E, Lester SL, Rischmueller M, Dodd T, Black R, Ahern $\mathrm{M}$, et al. Epidemiology of biopsy-proven giant cell arteritis in South Australia. Intern Med J. 2014;44(1):32-9.

First published study providing us data with epidemiology of giant cell arteritis in Australia.

15. Gonzalez-Gay MA, Miranda-Filloy JA, Lopez-Diaz MJ, Perez-Alvarez R, Gonzalez-Juanatey C, SanchezAndrade A, et al. Giant cell arteritis in northwestern Spain: a 25-year epidemiologic study. Medicine (Baltimore). 2007;86(2):61-8.

16. Nordborg C, Johansson H, Petursdottir V, Nordborg E. The epidemiology of biopsy-positive giant cell arteritis: special reference to changes in the age of the population. Rheumatology (Oxford). 2003;42(4):549-52.

17. Nesher G, Gur H, Ehrenfeld M, Rubinow A, Sonnenblick M. The changing clinical presentation of temporal arteritis in Israel: a multicenter study. Isr Med Assoc J. 1999;1(1):17-9.

18. Kermani TA, Schafer VS, Crowson CS, Hunder GG, Gabriel SE, Matteson EL, et al. Increase in age at onset of giant cell arteritis: a population-based study. Ann Rheum Dis. 2010;69(4):780-1.

19. Boesen P, Sorensen SF. Giant cell arteritis, temporal arteritis, and polymyalgia rheumatica in a Danish county. A prospective investigation, 1982-1985. Arthritis Rheum. 1987;30(3):294-9.

20. Gran JT, Myklebust G. The incidence of polymyalgia rheumatica and temporal arteritis in the county of Aust
Agder, south Norway: a prospective study 1987-94. J Rheumatol. 1997;24(9):1739-43.

21. Haugeberg G, Paulsen PQ, Bie RB. Temporal arteritis in Vest Agder County in southern Norway: incidence and clinical findings. J Rheumatol. 2000;27(11):2624-7.

22. Nordborg E, Bengtsson BA. Epidemiology of biopsyproven giant cell arteritis (GCA). J Intern Med. 1990;227(4):233-6.

23. Bengtsson BA, Malmvall BE. The epidemiology of giant cell arteritis including temporal arteritis and polymyalgia rheumatica. Incidences of different clinical presentations and eye complications. Arthritis Rheum. 1981;24(7):899-904.

24. Baldursson O, Steinsson K, Bjornsson J, Lie JT. Giant cell arteritis in Iceland. An epidemiologic and histopathologic analysis. Arthritis Rheum. 1994;37(7):1007-12.

25. Petursdottir V, Johansson H, Nordborg E, Nordborg C. The epidemiology of biopsy-positive giant cell arteritis: special reference to cyclic fluctuations. Rheumatology (Oxford). 1999;38(12):1208-12.

26. Petri H, Nevitt A, Sarsour K, Napalkov P, Collinson N. Incidence of giant cell arteritis and characteristics of patients: data-driven analysis of comorbidities. Arthritis Care Res (Hoboken). 2015;67(3):390-5.

27. Romero-Gomez C, Aguilar-Garcia JA, Garcia-de-Lucas MD, Cotos-Canca R, Olalla-Sierra J, Garcia-Alegria JJ, et al. Epidemiological study of primary systemic vasculitides among adults in southern Spain and review of the main epidemiological studies. Clin Exp Rheumatol. 2015;33(2 Suppl 89):S-11-8.

28. Salvarani C, Gabriel SE, O'Fallon WM, Hunder GG. The incidence of giant cell arteritis in Olmsted County, Minnesota: apparent fluctuations in a cyclic pattern. Ann Intern Med. 1995;123(3):192-4.

29. Reinhold-Keller E, Zeidler A, Gutfleisch J, Peter HH, Raspe HH, Gross WL. Giant cell arteritis is more prevalent in urban than in rural populations: results of an epidemiological study of primary systemic vasculitides in Germany. Rheumatology (Oxford).

2000;39(12):1396-402.

30. Smeeth L, Cook C, Hall AJ. Incidence of diagnosed polymyalgia rheumatica and temporal arteritis in the United Kingdom, 1990-2001. Ann Rheum Dis. 2006;65(8):1093-8.

31. Smith CA, Fidler WJ, Pinals RS. The epidemiology of giant cell arteritis. Report of a ten-year study in Shelby County, Tennessee. Arthritis Rheum.

1983;26(10):1214-9.

32. Ramstead CL, Patel AD. Giant cell arteritis in a neuroophthalmology clinic in Saskatoon, 1998-2003. Can J Ophthalmol. 2007;42(2):295-8.

33. Mader TH, Werner RP, Chamberlain DG, Doornbos D. Giant cell arteritis in Alaska Natives. Can J

Ophthalmol. 2009;44(1):53-6.

34. Pereira LS, Yoon MK, Hwang TN, Hong JE, Ray K, Porco T, et al. Giant cell arteritis in Asians: a comparative study. Br J Ophthalmol. 2011;95(2):214-6. 
35. Guerra A, Magraner M, Serrano L, Bredy R. Temporal arteritis in Puerto Rico Hispanics. Bol Asoc Med P R. 2006;98(4):304-11.

36. Lam BL, Wirthlin RS, Gonzalez A, Dubovy SR, Feuer WJ. Giant cell arteritis among Hispanic Americans. Am J Ophthalmol. 2007;143(1):161-3.

37. Alba MA, Mena-Madrazo JA, Reyes E, Flores-Suarez LF. Giant cell arteritis in Mexican patients. J Clin Rheumatol. 2012;18(1):1-7.

38. Abdul-Rahman AM, Molteno AC, Bevin TH. The epidemiology of giant cell arteritis in Otago, New Zealand: a 9-year analysis. N Z Med J. 2011;124(1329):44-52.

First publication which provides us with data on the epidemiology of giant cell arteritis in New Zealand.

39. Bas-Lando M, Breuer GS, Berkun Y, Mates M, Sonnenblick M, Nesher G. The incidence of giant cell arteritis in Jerusalem over a 25-year period: annual and seasonal fluctuations. Clin Exp Rheumatol. 2007;25(1 Suppl 44):S15-7.

40. Pamuk ON, Donmez S, Karahan B, Pamuk GE, Cakir N. Giant cell arteritis and polymyalgia rheumatica in northwestern Turkey: clinical features and epidemiological data. Clin Exp Rheumatol. 2009;27(5):830-3.

41. Kobayashi S, Yano T, Matsumoto Y, Numano F, Nakajima N, Yasuda K, et al. Clinical and epidemiologic analysis of giant cell (temporal) arteritis from a nationwide survey in 1998 in Japan: the first government-supported nationwide survey. Arthritis Rheum. 2003;49(4):594-8.

42. Singh S, Balakrishnan C, Mangat G, Samant R, Bambani M, Kalke S, et al. Giant cell arteritis in Mumbai. J Assoc Physicians India. 2010;58:372-4.

43. Chaudhry IA, Shamsi FA, Elzaridi E, Arat YO, Bosley TM, Riley FC. Epidemiology of giant-cell arteritis in an Arab population: a 22-year study. Br J Ophthalmol. 2007;91(6):715-8.

44. Khalifa M, Karmani M, Jaafoura NG, Kaabia N, Letaief AO, Bahri F. Epidemiological and clinical features of giant cell arteritis in Tunisia. Eur J Intern Med. 2009;20(2):208-12.

45.•• Carmona FD, Gonzalez-Gay MA, Martin J. Genetic component of giant cell arteritis. Rheumatology (Oxford). 2014;53(1):6-18.

Excellent and comprehensive review article on the genetics of giant cell arteritis.

46. Serrano A, Marquez A, Mackie SL, Carmona FD, Solans R, Miranda-Filloy JA, et al. Identification of the PTPN22 functional variant R620W as susceptibility genetic factor for giant cell arteritis. Ann Rheum Dis. 2013;72(11):1882-6.

Recent publication on the genetic susceptibility of giant cell arteritis which found that polymorphissm in PTPN22 which has been associated with susceptibility to other autoimmune diseases may also play a role in giant cell arteritis.

47. Marquez A, Hernandez-Rodriguez J, Cid MC, Solans R, Castaneda S, Fernandez-Contreras ME, et al. Influence of the IL17A locus in giant cell arteritis susceptibility. Ann Rheum Dis. 2014;73(9):1742-5.
Study which found polymorphisms in IL17A may confer susceptibility to giant cell arteritis keeping with other reports which have shown IL-17 plays a role in the pathogenesis of this disease.

48. Kisza K, Murchison AP, Dai Y, Bilyk JR, Eagle Jr RC, Sergott R, et al. Giant cell arteritis incidence: analysis by season and year in mid-Atlantic United States. Clin Experiment Ophthalmol. 2013;41(6):577-81.

49. Sonnenblick M, Nesher G, Friedlander Y, Rubinow A. Giant cell arteritis in Jerusalem: a 12-year epidemiological study. Br J Rheumatol. 1994;33(10):938-41.

50. Gilden D, White T, Khmeleva N, Heintzman A, Choe A, Boyer PJ, et al. Prevalence and distribution of VZV in temporal arteries of patients with giant cell arteritis. Neurology. 2015;84(19):1948-55.

This study provides data that varicella zoster virus may play a role in the pathogenesis ofs giant cell arteritis.

51. Mackie SL, Dasgupta B, Hordon L, Gough A, Green M, Hollywood J, et al. Ischaemic manifestations in giant cell arteritis are associated with area level socioeconomic deprivation, but not cardiovascular risk factors. Rheumatology (Oxford). 2011;50(11):2014-22.

52. Zoller B, Li X, Sundquist J, Sundquist K. Occupational and socio-economic risk factors for giant cell arteritis: a nationwide study based on hospitalizations in Sweden. Scand J Rheumatol. 2013;42(6):487-97.

53. Dasgupta B, Borg FA, Hassan N, Alexander L, Barraclough K, Bourke B, et al. BSR and BHPR guidelines for the management of giant cell arteritis. Rheumatology (Oxford). 2010;49(8):1594-7.

54. Mukhtyar C, Guillevin L, Cid MC, Dasgupta B, de Groot K, Gross W, et al. EULAR recommendations for the management of large vessel vasculitis. Ann Rheum Dis. 2009;68(3):318-23.

55. Hunder GG, Sheps SG, Allen GL, Joyce JW. Daily and alternate-day corticosteroid regimens in treatment of giant cell arteritis: comparison in a prospective study. Ann Intern Med. 1975;82(5):613-8.

56. Mazlumzadeh M, Hunder GG, Easley KA, Calamia KT, Matteson EL, Griffing WL, et al. Treatment of giant cell arteritis using induction therapy with high-dose glucocorticoids: a double-blind, placebo-controlled, randomized prospective clinical trial. Arthritis Rheum. 2006;54(10):3310-8.

57. Chevalet P, Barrier JH, Pottier P, Magadur-Joly G, Pottier MA, Hamidou M, et al. A randomized, multicenter, controlled trial using intravenous pulses of methylprednisolone in the initial treatment of simple forms of giant cell arteritis: a one year followup study of 164 patients. J Rheumatol. 2000;27(6):1484-91.

58. Lundberg I, Hedfors E. Restricted dose and duration of corticosteroid treatment in patients with polymyalgia rheumatica and temporal arteritis. J Rheumatol. 1990;17(10):1340-5.

59. Nesher G, Rubinow A, Sonnenblick M. Efficacy and adverse effects of different corticosteroid dose regimens in temporal arteritis: a retrospective study. Clin Exp Rheumatol. 1997;15(3):303-6. 
60. Delecoeuillerie G, Joly P, Cohen de Lara A, Paolaggi JB. Polymyalgia rheumatica and temporal arteritis: a retrospective analysis of prognostic features and different corticosteroid regimens (11 year survey of 210 patients). Ann Rheum Dis. 1988;47(9):733-9.

61. Les I, Pijoan JI, Rodriguez-Alvarez R, Ruiz-Irastorza G, Martinez-Berriotxoa A. Effectiveness and safety of medium-dose prednisone in giant cell arteritis: a retrospective cohort study of 103 patients. Clin Exp Rheumatol. 2015;33(2 Suppl 89):S-90-7.

62.•• Weyand CM, Goronzy JJ. Immune mechanisms in medium and large-vessel vasculitis. Nat Rev Rheumatol. 2013;9(12):731-40.

Comprehensive review article outlining the cellular pathways and cytokines involved in the pathogenesis of giant cell arteritis.

63. Deng J, Younge BR, Olshen RA, Goronzy JJ, Weyand $\mathrm{CM}$. Th17 and Th1 T-cell responses in giant cell arteritis. Circulation. 2010;121(7):906-15.

64. Fritzlen J, Younge BR, Weyand CM, Hunder GG, Warrington KJ, Maleszewski J. Second temporal artery biopsies in patients with temporal arteritis. Arthritis Rheumatol. 2015;67:(suppl 10).

65. Spiera RF, Mitnick HJ, Kupersmith M, Richmond M, Spiera H, Peterson MG, et al. A prospective, doubleblind, randomized, placebo controlled trial of methotrexate in the treatment of giant cell arteritis (GCA). Clin Exp Rheumatol. 2001;19(5):495-501.

66. Jover JA, Hernandez-Garcia C, Morado IC, Vargas E, Banares A, Fernandez-Gutierrez B. Combined treatment of giant-cell arteritis with methotrexate and prednisone: a randomized, double-blind, placebocontrolled trial. Ann Intern Med. 2001;134(2):106-14.

67. Hoffman GS, Cid MC, Hellmann DB, Guillevin L, Stone JH, Schousboe J, et al. A multicenter, randomized, double-blind, placebo-controlled trial of adjuvant methotrexate treatment for giant cell arteritis. Arthritis Rheum. 2002;46(5):1309-18.

68. Mahr AD, Jover JA, Spiera RF, Hernandez-Garcia C, Fernandez-Gutierrez B, Lavalley MP, et al. Adjunctive methotrexate for treatment of giant cell arteritis: an individual patient data meta-analysis. Arthritis Rheum. 2007;56(8):2789-97.

69. Quartuccio L, Maset M, De Maglio G, Pontarini E, Fabris M, Mansutti E, et al. Role of oral cyclophosphamide in the treatment of giant cell arteritis. Rheumatology (Oxford). 2012;51(9):1677-86.

70. Loock J, Henes J, Kotter I, Witte T, Lamprecht P, Schirmer M, et al. Treatment of refractory giant cell arteritis with cyclophosphamide:a retrospective analysis of 35 patients from three centres. Clin Exp Rheumatol. 2012;30(1 Suppl 70):S70-6.

71. Henes JC, Mueller M, Pfannenberg C, Kanz L, Koetter I Cyclophosphamide for large vessel vasculitis: assessment of response by PET/CT. Clin Exp Rheumatol. 2011;29(1 Suppl 64):S43-8.

72. - de Boysson H, Boutemy J, Creveuil C, Ollivier Y, Letellier $\mathrm{P}$, Pagnoux $\mathrm{C}$, et al. Is there a place for cyclophosphamide in the treatment of giant-cell arteritis? A case series and systematic review. Semin Arthritis Rheum. 2013;43(1):105-12.

This systematic review comprehensively outlines the available information regarding the use of cyclophosphamide in giant cell arteritis.

73. Diamantopoulos AP, Hetland H, Myklebust G. Leflunomide as a corticosteroid-sparing agent in giant cell arteritis and polymyalgia rheumatica: a case series. Biomed Res Int. 2013;2013:120638.

74. Adizie T, Christidis D, Dharmapaliah C, Borg F, Dasgupta B. Efficacy and tolerability of leflunomide in difficult-totreat polymyalgia rheumatica and giant cell arteritis: a case series. Int J Clin Pract. 2012;66(9):906-9.

75. De Silva M, Hazleman BL. Azathioprine in giant cell arteritis/polymyalgia rheumatica: a double-blind study. Ann Rheum Dis. 1986;45(2):136-8.

76. Sciascia S, Piras D, Baldovino S, Russo A, Naretto C, Rossi D, et al. Mycophenolate mofetil as steroidsparing treatment for elderly patients with giant cell arteritis: report of three cases. Aging Clin Exp Res. 2012;24(3):273-7.

77. Goel R, Danda D, Mathew J, Edwin N. Mycophenolate mofetil in Takayasu's arteritis. Clin Rheumatol. 2010;29(3):329-32.

78. Hernandez-Rodriguez J, Segarra M, Vilardell C, Sanchez M, Garcia-Martinez A, Esteban MJ, et al. Tissue production of pro-inflammatory cytokines (IL-1beta, TNFalpha and IL-6) correlates with the intensity of the systemic inflammatory response and with corticosteroid requirements in giant-cell arteritis. Rheumatology (Oxford). 2004;43(3):294-301.

79.• Samson M, Audia S, Janikashvili N, Bonnotte B. Is TNFalpha really involved in giant cell arteritis pathogenesis? Ann Rheum Dis. 2014;73(1):e1.

This brief report challenges the role of TNF-alpha in giant cell arteritis by demonstrating a lack of increase among patients with active disease compared to controls.

80. Hoffman GS, Cid MC, Rendt-Zagar KE, Merkel PA, Weyand $\mathrm{CM}$, Stone JH, et al. Infliximab for maintenance of glucocorticosteroid-induced remission of giant cell arteritis: a randomized trial. Ann Intern Med. 2007;146(9):621-30.

81. Martinez-Taboada VM, Rodriguez-Valverde V, Carreno L, Lopez-Longo J, Figueroa M, Belzunegui J, et al. A double-blind placebo controlled trial of etanercept in patients with giant cell arteritis and corticosteroid side effects. Ann Rheum Dis. 2008;67(5):625-30.

82. Seror R, Baron G, Hachulla E, Debandt M, Larroche C, Puechal $\mathrm{X}$, et al. Adalimumab for steroid sparing in patients with giant-cell arteritis: results of a multicentre randomised controlled trial. Ann Rheum Dis. 2014;73(12):2074-81.

83. Adler S, Reichenbach S, Kuchen S, Wermelinger F, Dan D, PM. V, et al. Tocilizumab for the treatment of giant cell arteritis-a randomized placebo-controlled trial. Arthritis Rheumatol. 2015;67:(suppl 10).

84. Langford C, Cuthbertson D, Ytterberg S, Khalidi N, Monach P, Carette S, et al. A randomized double-blind trial of abatacept and glucocorticoids for the treatment 
of giant cell arteritis. Arthritis Rheumatol.

2015;67:(suppl 10).

85. Ly KH, Stirnemann J, Liozon E, Michel M, Fain O, Fauchais AL. Interleukin-1 blockade in refractory giant cell arteritis. Joint Bone Spine. 2014;81(1):76-8.

86. Conway R, O'Neill L, O'Flynn E, McCarthy G, Murphy $\mathrm{C}$, Veale $\mathrm{D}$, et al. Ustekinumab for the treatment of refractory giant cell arteritis Arthritis Rheumatol. 2015;67:(suppl 10).

87. Mayrbaeurl B, Hinterreiter M, Burgstaller S, Windpessl $\mathrm{M}$, Thaler J. The first case of a patient with neutropenia and giant-cell arteritis treated with rituximab. Clin Rheumatol. 2007;26(9):1597-8.

88. Bhatia A, Ell PJ, Edwards JC. Anti-CD20 monodonal antibody (rituximab) as an adjunct in the treatment of giant cell arteritis. Ann Rheum Dis. 2005;64(7):1099-100.

89. Weyand CM, Kaiser M, Yang H, Younge B, Goronzy JJ. Therapeutic effects of acetylsalicylic acid in giant cell arteritis. Arthritis Rheum. 2002;46(2):457-66.

90. Lee MS, Smith SD, Galor A, Hoffman GS. Antiplatelet and anticoagulant therapy in patients with giant cell arteritis. Arthritis Rheum. 2006;54(10):3306-9.

91. Nesher G, Berkun Y, Mates M, Baras M, Rubinow A, Sonnenblick M. Low-dose aspirin and prevention of cranial ischemic complications in giant cell arteritis. Arthritis Rheum. 2004;50(4):1332-7.

92. Gonzalez-Gay MA, Pineiro A, Gomez-Gigirey A, Garcia-Porrua C, Pego-Reigosa R, Dierssen-Sotos T, et al. Influence of traditional risk factors of atherosclerosis in the development of severe ischemic complications in giant cell arteritis. Medicine (Baltimore).

2004;83(6):342-7.

93. Narvaez J, Bernad B, Gomez-Vaquero C, Garcia-Gomez C, Roig-Vilaseca D, Juanola X, et al. Impact of antiplatelet therapy in the development of severe ischemic complications and in the outcome of patients with giant cell arteritis. Clin Exp Rheumatol. 2008;26(3 Suppl 49):S57-62.

94. Salvarani C, Della Bella C, Cimino L, Macchioni $\mathrm{P}$, Formisano D, Bajocchi G, et al. Risk factors for severe cranial ischaemic events in an Italian population-based cohort of patients with giant cell arteritis. Rheumatology (Oxford). 2009;48(3):250-3.

95.• Martinez-Taboada VM, Lopez-Hoyos M, Narvaez J, Munoz-Cacho P. Effect of antiplatelet/anticoagulant therapy on severe ischemic complications in patients with giant cell arteritis: a cumulative meta-analysis. Autoimmun Rev. 2014;13(8):788-94.

Excellent and comprehensive meta-analsysis evaluating the benefit of anti-platelet therapy in patient with giant cell arteritis.

96. Souza AW, Okamoto KY, Abrantes F, Schau B, Bacchiega AB, Shinjo SK. Giant cell arteritis: a multicenter observational study in Brazil. Clinics (Sao Paulo). 2013;68(3):317-22.

97. Satoh M, Takahashi Y, Tabuchi T, Minami Y, Tamada M, Takahashi K, et al. Cellular and molecular mechanisms of statins: an update on pleiotropic effects. Clin Sci (Lond). 2015;129(2):93-105.

98. Schmidt J, Kermani TA, Muratore F, Crowson CS, Matteson EL, Warrington KJ. Statin use in giant cell arteritis: a retrospective study. J Rheumatol. 2013;40(6):910-5.

99.• Pugnet G, Sailler L, Bourrel R, Montastruc JL, LapeyreMestre $\mathrm{M}$. Is statin exposure associated with occurrence or better outcome in giant cell arteritis? Results from a French population-based study. J Rheumatol. 2015;42(2):316-22.

This large population-based study evaluating the role of statin therapy in giant cell arteritis found no association with this medication and disease occurrence and minimal benefit in corticosteroid tapering.

100. Narvaez J, Bernad B, Nolla JM, Valverde J. Statin therapy does not seem to benefit giant cell arteritis. Semin Arthritis Rheum. 2007;36(5):322-7.

101. Garcia-Martinez A, Hernandez-Rodriguez J, Grau JM, Cid MC. Treatment with statins does not exhibit a clinically relevant corticosteroid-sparing effect in patients with giant cell arteritis. Arthritis Rheum. 2004;51(4):674-8.

102. Ostberg G. Temporal arteritis in a large necropsy series. Ann Rheum Dis. 1971;30(3):224-35.

103. Ostberg G. An arteritis with special reference to polymyalgia arteritica. Acta Pathol Microbiol Scand Suppl. 1973;237 Suppl 237:1-59.

104. Czihal M, Piller A, Schroettle A, Kuhlencordt PJ, Schulze-Koops H, Hoffmann U. Outcome of giant cell arteritis of the arm arteries managed with medical treatment alone: cross-sectional follow-up study. Rheumatology (Oxford). 2013;52(2):282-6.

105. Kermani TA, Matteson EL, Hunder GG, Warrington KJ. Symptomatic lower extremity vasculitis in giant cell arteritis: a case series. J Rheumatol. 2009;36(10):2277-83.

106. Assie C, Janvresse A, Plissonnier D, Levesque H, Marie I. Long-term follow-up of upper and lower extremity vasculitis related to giant cell arteritis: a series of 36 patients. Medicine (Baltimore). 2011;90(1):40-51.

107. Erbel R, Aboyans V, Boileau C, Bossone E, Bartolomeo RD, Eggebrecht H, et al. 2014 ESC Guidelines on the diagnosis and treatment of aortic diseases: document covering acute and chronic aortic diseases of the thoracic and abdominal aorta of the adult. The Task Force for the Diagnosis and Treatment of Aortic Diseases of the European Society of Cardiology (ESC). Eur Heart J. 2014;35(41):2873-926. 